
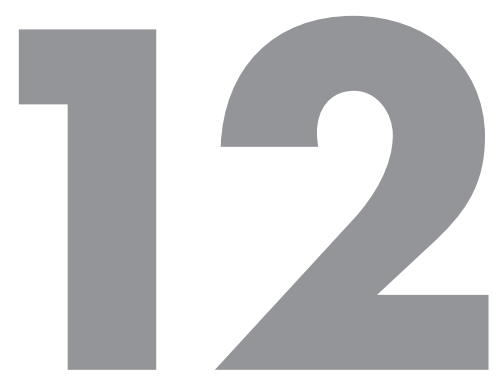

\title{
AÇÃO RESCISÓRIA ATÍPICA
}

O legislador tratou da coisa julgada como cláusula pétrea (art. $60, \mathbb{\$} 4^{\circ}$, IV, da CF), o que significa dizer que a coisa julgada não pode ser suprimida ou excluída do sistema positivado, nem por lei e nem mesmo por emenda constitucional. ${ }^{1}$ A alteração que se permite via ação rescisória poderia levar o intérprete, inclusive, a pensar que a norma inserta no art. 966 do CPC/2015 padeceria do vício de inconstitucionalidade. Todavia, justamente se aplica aqui o princípio da proporcionalidade, em face da gravidade maior de se manter no sistema uma sentença viciada pelas hipóteses de cabimento descritas no art. 966 do CPC/2015. ${ }^{2}$ A constitucionalidade do dispositivo é tranquila. Em que pesem esses argumentos, a modificação da decisão já estabilizada deve ser excepcional, pois depõe contra a prestigiosa instituição do Poder Judicante.

1 A redação do art. 485 e de seus incisos "seria aparentemente inconstitucional". (NERY JÚNIOR, Nelson. Princípios do processo civil na Constituição Federal, 8. ed., p. 50). Corresponde ao art. 485 do CPC/1973 o art. 966 do CPC/2015.

2 "A ação rescisória é um instrumento para tutela do direito ao processo justo e à decisão justa." (MARINONI, Luiz Guilherme; ARENHART, Sérgio Cruz; MITIDIERO, Daniel. Novo Código de Processo Civil comentado, p. 1020). 
A coisa julgada, como importante fator de pacificação social, não pode ser banalizada. Bem por isso, o rol do art. 966 do CPC/2015 é taxativo (numerus clausus), não sendo permitida interpretação extensiva. Todavia, admite-se, em tese, uma exceção. Como se trata de rol disciplinado em dispositivo infraconstitucional, então poderia ocorrer hipótese de infringência de garantia ou princípio de direito que, muito embora não expresso, prepondera no ordenamento jurídico como constitutivo do suporte fundante do direito vigente. Vale dizer, a infringência direta desse direito constitucional, muito embora não expresso textualmente, daria ensejo à ação rescisória atípica.

Nesse quadro, a ação rescisória típica é aquela permitida diretamente pelo texto da lei. Ao contrário, atípica ${ }^{3}$ se afigura ação rescisória que possa ser processada com suporte nas "chamadas garantias constitucional-processuais implícitas" ou na violação de princípio ${ }^{5}$ geral de direito (por exemplo, duplo grau de jurisdição, vedação ao retrocesso, vedação ao abuso de direito de postular, razoabilidade e ação rescisória com base na não recepção constitucional, ${ }^{6}$ todos imprescindíveis ao devido processo legal). ${ }^{7}$

A desconsideração de tais garantias e princípios enseja o cabimento da ação rescisória. O mister de dizer o direito é mais que aplicar o texto frio da lei e querer

3 PORTO, Sérgio Gilberto. Ação rescisória atípica. Instrumento de defesa da ordem jurídica. São Paulo: RT, 2009. p. 216.

4 "Cabe ação rescisória por ofensa à literal disposição constitucional, ainda que a decisão rescindenda tenha se baseado em interpretação controvertida ou seja anterior à orientação fixada pelo Supremo Tribunal Federal.” (STF - RE 328.812 ED/AM - Emb. Decl. no Recurso Extraordinário, Rel. Ministro Gilmar Mendes, julgado em 06.03.2008, Órgão Julgador: Tribunal Pleno).

5 Princípios "são mais do que normas, servindo de vetores para soluções interpretativas". (TEMER, Michel. Elementos de direito constitucional. 10. ed. São Paulo: Malheiro, 1994. p. 24).

6 Com base na não recepção constitucional, o TJSP proferiu decisão acolhendo violação aos arts. $1^{\circ}$, inciso IV, e 170, inciso VIII, julgando procedente a ação rescisória com fundamento em ação tipificada no art. 485, inciso V, do CPC. Confira-se o Voto n. 3246 na Ação Rescisória 0137832-95.2011.8.26.0000, São Paulo, Rel. Paulo Galizia, TJSP, registro 2012.0000193843, julgado em 23.04.2012. Corresponde ao art. 485, inciso V, do CPC/1973 o art. 966, inciso V, do CPC/2015.

7 SACCO NETO, Fernando. Do cabimento da ação rescisória com fundamento em violação de princípio geral de direito. In: MEDINA, José Miguel Garcia; CRUZ, Luana Pedrosa de Figueiredo; CERQUEIRA, Luís Otávio Sequeira de; GOMES JÚNIOR, Luiz Manoel (Coord.). Os poderes do juiz e o controle das decisões judiciais: estudos em homenagem à Professora Teresa Arruda Alvim Wambier. São Paulo: RT, 2008. p. 1021. 
entender o art. 966 do CPC/2015 como taxativo ${ }^{8}$ ou, pelo inciso V, aplicar um sentido literal para afastar o cabimento da ação rescisória. ${ }^{9} \mathrm{O}$ atual sentido de legalidade é a aplicação da norma jurídica conforme o direito que se revela no cotejo da jurisprudência e da doutrina, que demonstra o seu valor. ${ }^{10}$

Com a edição do CPC de 2015, houve a substituição, no inciso V do art. 966 (art. 485 do CPC/1973), do termo "literal disposição de lei” por "norma jurídica”. "Não estão só na 'letra de lei' os limites do ordenamento jurídico; e nem só do atendimento à literalidade do texto, muito pelo contrário, existe violação de norma jurídica. Na literalidade, pois, do novo inc. V constitui causa de rescindibilidade "violar manifestamente norma jurídica"". ${ }^{11}$

Os princípios e garantias participam do ordenamento jurídico, e, enquanto essa ideia não vinga plenamente, temos visto tais ações rescisórias serem recebidas e julgadas no mérito com base em uma leitura mais alargada ${ }^{12}$ do art. 966,

8 Sobre o princípio da taxatividade ou legalidade numerus clausus, vide: ALVIM NETTO, José Manoel de Arruda. Anotações sobre a teoria geral dos recursos. In: NERY JÚNIOR, Nelson; WAMBIER, Teresa Arruda Alvim (Coord.). Aspectos polêmicos e atuais dos recursos cíveis de acordo com a Lei n. 9.756/98. São Paulo: RT, 1999. p. 56.

9 A Comissão Revisora do CPC atual sugeriu a substituição do termo "literal disposição de lei" do inciso V do art. 485, para "direito em tese", visando evitar entendimentos errôneos. "O ordenamento jurídico evidentemente não se exaure naquilo que a letra da lei revela à primeira vista. Nem é menos grave o erro do julgador na solução da quaestio iuris quando afronte norma que integra o ordenamento sem constar literalmente de texto algum.” MOREIRA, José Carlos Barbosa. Comentários ao Código de Processo Civil. Rio de Janeiro: Forense, 2001. p. 130. Corresponde ao art. 485 do CPC/1973 o art. 966 do CPC/2015.

10 Não são incomuns até mesmo decisões contra legem, pois a legislação definitivamente não acompanha as mutações sociais, que ocorrem a todo instante. Assim, "leis escritas nada mais são que traços exteriores, mais ou menos acidentais, do conteúdo real do direito objetivo independentemente do direito ser escrito ou não, uma vez violado”. PONTES DE MIRANDA, Francisco Cavalcanti. Tratado da ação rescisória. 3. ed. Rio de Janeiro: Borsoi, 1957. p. 161.

11 MAZZEI, Rodrigo; GONÇALVES, Tiago Figueiredo. Primeiras linhas sobre a disciplina da ação rescisória no CPC/2015. In: DIDIER JR., Fredie (coord.); MACÊDO, Lucas Buril de; PEIXOTO, Ravi; FREIRE, Alexandre. Novo CPC - doutrina selecionada, v. 6: processo nos tribunais e meios de impugnação às decisões judiciais, p. 253.

12 "Questão análoga (...) consiste em saber se a disposição do inciso V do art. 485 é abrangente não apenas da lei (ou o direito 'escrito'), mas dos princípios gerais do direito. A esse propósito, não parece representar indevido alargamento do texto do art. 485 do CPC - cujas hipóteses são sabidamente taxativas - a resposta positiva. Se o pressuposto essencial da ação rescisória (até mesmo para além do plano jurídico) é, em hipóteses relevantes e de reconhecida gravidade, impedir a subsistência de decisão que afronte o valor 'justiça' (ainda que isso venha em detrimento 
inciso $\mathrm{V}$, do $\mathrm{CPC} / 2015 .{ }^{13}$ Isso porque os princípios gerais de direito, assim como a analogia e os costumes, são regras jurídicas reconhecidas pela lei e, por isso, quando flagrada sua transgressão, tem-se por viabilizada a ação rescisória. ${ }^{14-15}$

do valor 'segurança'), então, não se pode descartar que tais hipóteses decorram precisamente da violação não apenas ao texto de lei. Se o sistema aceita que a lei não é a fonte exclusiva do direito, então, não há sentido em restringir a previsão legal, sem que isso, naturalmente, signifique permitir, em ação rescisória, o reexame de toda e qualquer decisão, por todo e qualquer fundamento, como se tal remédio fosse, como dito, uma nova instância recursal." (YARSHELL, Flávio Luiz. Ação rescisória - juízo rescindente e rescisório, p. 323). Corresponde ao art. 485, inciso V, do CPC/1973, o art. 966, inciso V, do CPC/2015.

13 WAMBIER, Teresa Arruda Alvim; MEDINA, José Miguel Garcia. Relativização da coisa julgada. In: MARINONI, Luiz Guilherme (Org.). Estudos de direito processual civil: homenagem ao professor Egas Dirceu Moniz de Aragão. São Paulo, 2005. p. 537.

14 Preciso, acerca de tal assunto, o seguinte escólio: "É admissível a ação rescisória, com base no CPC 485, V, por ofensa à analogia, aos costumes e aos princípios gerais de direito, porque são regras jurídicas com precisão expressa na lei $\left(\operatorname{LICC}, 4^{\circ}\right)(\ldots)$ e, portanto, fontes de direito, equiparando-se à lei em sentido amplo (...)”. (NERY JÚNIOR, Nelson; NERY, Rosa Maria de Andrade. Código de processo civil comentado e legislação extravagante, 10. ed., p. 779). Corresponde ao art. 485, inciso V, do CPC/1973 o art. 966, inciso V, do CPC/2015.

15 "Processual Civil e Previdenciário. Agravo Interno no Recurso Especial. Enunciado administrativo 3/STJ. Ação rescisória. Decadência. Questão não analisada pela administração previdenciária. Violação do artigo 966, V, do CPC/2015. Súmula 343/STJ. Agravo interno não provido. 1. A ação rescisória, com base no artigo 966, V, do CPC/2015, pressupõe ofensa direta e frontal a dispositivo legal, por isso que, tratando-se, como na espécie, de decisão que adota uma dentre duas ou mais interpretações possíveis para o mesmo regramento, não se poderá, em tal contexto, descortinar hipótese de violação literal de lei, capaz de legitimar o emprego do mecanismo corretivo rescisório. 2. Vale destacar que 'O cabimento da Ação Rescisória com base em violação a disposição literal de lei somente se justifica quando a ofensa se mostre aberrante, cristalina, observada primo ictu oculi, consubstanciada no desprezo do sistema jurídico (normas e princípios) pelo julgado rescindendo. Esta ofensa, por si só, não se caracteriza com o fato de haver decisões favoráveis à tese que foi rechaçada pela decisão que se pretende rescindir; não há rescisão por discrepância jurisprudencial, em especial quando se quer impor a retroação de precedentes judiciais afluentes.' (REsp 1.458.607/SC, Primeira Turma, Relator Ministro Napoleão Nunes Maia Filho, julgado em 23/10/2014, DJe 3/11/2014). 3. Ao analisar o caso dos autos, o Tribunal a quo assentou que o tema ficou pacificado pelo STF no julgamento do RE 626.489, incidindo, no caso, a Súmula 343/STF, posto que 'a pacificação da jurisprudência desta Corte em sentido contrário e posteriormente ao acórdão rescindendo não afasta a aplicação do enunciado n. 343 da Súmula do STF.' (REsp 736.650/MT, Corte Especial, Relator Ministro Antonio Carlos Ferreira, julgado em 20/8/2014, DJe 1/9/2014). 4. Agravo interno não provido". (STJ - AgInt no REsp 1691830 RS 2017/0202316-2, Rel. Ministro Mauro Campbell Marques, julgado em 20.02.2018, T2 - Segunda Turma, DJe 26.02.2018). 
Para a "teoria do direito é praticamente assente que tanto as regras jurídicas quanto os princípios constituem espécies de normas jurídicas, e que mesmo os princípios implícitos são dotados de positivação. Ao mesmo tempo, é indubitável que a norma jurídica não se confunde com o texto da lei, sendo, antes, o resultado da atribuição de sentido ao texto". ${ }^{16}$

Anote-se, por derradeiro, que a propalada atipicidade, se adotada, reside nos fundamentos da ação rescisória, e não nos pressupostos mínimos de admissibilidade e cabimento (depósito, nos casos em que comportar, e sentença de mérito transitada em julgado). ${ }^{17}$

16 MAZZEI, Rodrigo; GONÇALVES, Tiago Figueiredo. Primeiras linhas sobre a disciplina da ação rescisória no CPC/2015. In: DIDIER JR., Fredie (coord.); MACÊDO, Lucas Buril de; PEIXOTO, Ravi; FREIRE, Alexandre. Novo CPC - doutrina selecionada, v. 6: processo nos tribunais e meios de impugnação às decisões judiciais, p. 253.

17 O cabimento da ação rescisória atípica é uma necessidade atual e poderá, como visto no desenvolvimento da doutrina e da jurisprudência, na esteira do que vem acontecendo com os avanços no procedimento recursal, ganhar espaço em breve. Sobre a teoria dos recursos e sua evolução, a doutrina aponta que "o princípio da instrumentalidade das formas, que ora permeia o estudo do Processo Civil moderno, provocou uma considerável alteração na admissibilidade dos recursos em geral dentro do ordenamento jurídico do país, o que terminou por promover, de forma direta, uma maior amplitude na efetiva aplicação do princípio do acesso à justiça”. (COUTO, Mônica Bonetti; ANJOS, Luiz Cláudio Correia dos. A fungibilidade recursal e a função instrumental do processo: hipótese de ampliação do acesso à justiça. Anais do XVIII Congresso Nacional do CONPEDI, realizado em São Paulo - SP nos dias 4, 5, 6 e 7 de novembro de 2009, p. 2). 
